\title{
A note from the President
}

\author{
Trevor Hambley
}

(c) SBIC 2009

\section{The Society of Biological Inorganic Chemistry}

SBIC has been established as a learned society of advanced research and education in the field of Biological Inorganic Chemistry

\section{SBIC COUNCIL}

\section{President}

Trevor Hambley, Sydney, Australia

Past President

Robert A. Scott, Athens, GA, USA

Secretary

Charles Riordan, Newark, DE, USA

Treasurer

Graeme Hanson, St. Lucia, Australia

\author{
Members \\ Victoria A. DeRose, Berkeley, CA, USA \\ Juan C. Fontecilla-Camps, Grenoble, France \\ Julia A. Kovacs, Seattle, WA, USA \\ Janet R. Morrow, Amherst, NY, USA \\ José Moura, Lisbon, Portugal \\ Britt-Marie Sjöberg, Stockholm, Sweden \\ Andrew J. Thomson, Norwich, UK \\ Paola Turano, Florence, Italy
}

\author{
Chief Editor of JBIC \\ Lawrence Que Jr., Minneapolis, MN, USA \\ Program Committee/ICBIC-IOC \\ Kenneth D. Karlin, Baltimore, MD, USA \\ Nominations Committe \\ Lucia Banci, Florence, Italy \\ SBIC Website: \\ http://SBIChem.org
}

\section{ICBIC-14 Nagoya, Japan}

ICBIC-14 held in Nagoya, Japan, at the end of July was an outstanding success with more than 700 attendees, more than 400 from outside of the country. Professor Yoshi Watanabe, the conference Chair, his organizing committee and the many helpers are to be congratulated on the stimulating program and the impeccable organization. The conference was held in the Nagoya Congress Centre, the largest of its type in Japan, which provided numerous lecture theatres, meeting locations, and discussion opportunities. It also provided the largest, most comfortable poster venue I have encountered. This enabled the posters to be displayed and discussed throughout the meeting - a major contributor to the success and conviviality of the conference. Also notable was the food and hospitality: the lunch boxes provided at the conference, the stunning conference banquet, and the wonderful restaurants showed that Nagoya deserves is reputation for outstanding food.

A feature of the conference was the presentation of plenary lectures by the winners of the SBIC Early Career Awards for 2008 and 2009. As mentioned previously, these were won by Professor Marty Bollinger and Frank Neese respectively and their lectures demonstrated that each was a thoroughly deserving winner. Below is a picture of Marty and Frank (second from right and far left) with Bob Scott, Trevor Hambley, and Ed Solomon.

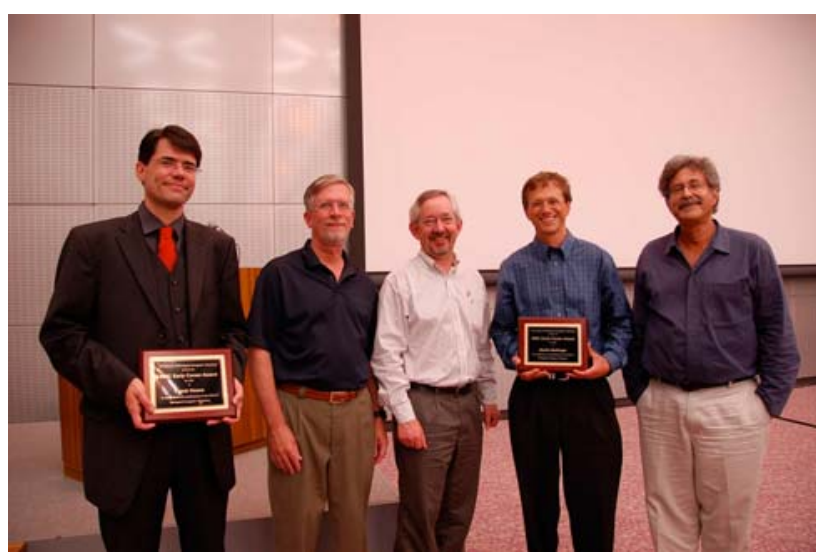

Trevor Hambley SBIC President 